\title{
The Rationality of Legal Discourse in Habermas's Discourse Theory
}

\section{Eveline T. Feteris}

\author{
University of Amsterdam
}

\begin{abstract}
This paper argues that Habermas's conception of the rationality of moral and legal discussions has import for argumentation theorists interested in the rationality of public deliberations in politics and law. I begin with a survey of Habermas's discourse theory and his criteria of rationality for moral and legal discourse. I then explain why, in his view, the forms of rational discourse in morality and law complement each other. My aim is to show how Habermas's account of this complementary relationship opens up fruitful perspectives for argumentation theory. Specifically, his thought can stimulate research regarding, on the one hand, the ways in which legal procedures provide for presumptively rational resolutions of moral disputes and, on the other hand, the applicability of ideal argumentation-theoretic models to the legal field. I conclude with a proposal for integrating Habermas's ideas in a research program for legal argumentation.
\end{abstract}

Résumé: La conception de la rationalité des discussions morales et légales d'Habermas a des conséquences théoriques pour ceux qui s'intéressent à la rationalité des décisions publiques, politiques et légales. Je commence avec un résumé de la théorie du discours d'Habermas et ses critères de rationalité dans le discours moral et légal. Ensuite j'explique pourquoi, selon Habermas, les formes de discours rationnels sont complémentaires. Mon but est de montrer comment l'explication de cette complémentarité par Habermas ouvre à des nouvelles perspectives pour la theorie de l'argumentation. Sa pensée peut faire évoluer notre compréhension des procédés légaux qui visent à résoudre rationnellement des disputes morales. De plus, on peut faire appel aux idées d'Habermas dans l'application des modèles théoriques de l'argumentation au champ légal. Je conclus en proposant une façon spécifique d'intégrer la théorie d'Habermas dans un programme de recherche pour l'argumentation légale.

Keywords: rationality, legal argumentation, rational consensus, practical discourse.

\section{Introduction}

Argumentation theorists have always been interested in the relation between legal discourse and ideal models of rational discussion. Authors such as Perelman and Olbrechts-Tyteca (1958) and Toulmin (1958) have illustrated one side of this relation by presenting the law as an example of a rational enterprise that can function as a model for rational discussion in the moral sphere. The other sidenamely, how general ideals of rational argumentation can function as a critical instrument for assessing the quality of argumentation in the legal sphere-has scarcely been investigated.

The German philosopher Jürgen Habermas $(1988,1990,1996)$ has explored both sides of the relation between the rationality of legal discourse and the ration- 
ality of discourse in everyday life. In his view, these forms of rationality are complementary: on the one hand, legal procedures can promote the rational quality of legal discourse on moral issues in relation to the idealized requirements of rational discussion; on the other hand, these idealized requirements should function as a standard for the rationality of legal procedures. As I hope to show, Habermas's discourse theory of law, and particularly his philosophical account of the complementary relationship between law and rational discourse, opens up interesting perspectives for research in argumentation theory. However, much work remains to be done at the level of detailed analysis of legal discussions and argumentative texts. How exactly do legal procedures provide for presumptively rational resolutions of moral disputes? How do we apply ideal models developed in argumentation theory to the legal field? To address such questions, Habermas's model, as it presently stands, requires supplementation. For this I look to the pragma-dialectical model as a source of further ideas for a research program in legal argumentation. More specifically, I describe how one might extend Habermas's initiatives by distinguishing and elaborating philosophical, theoretical, analytical, empirical, and pragmatic components.

Although Habermas's work on the rationality of moral and legal discourse is familiar to many philosophers, argumentation theorists tend to be less acquainted with his thought. I thus start, in section 2 , by sketching his general discourse theory, the ideal of rational consensus, and the necessity of institutionalizing rational discourses in institutional settings such as the law. Of necessity, I concentrate on those aspects that are relevant for argumentation theory, leaving aside the philosophical implications of Habermas's approach.' In section 3, I explore in detail the complementary relation between moral-practical discourse and legal discourse. I then proceed, in section 4, to situate Habermas's theory of rational legal argumentation in the context of a research program in the study of argumentation; we will then be in a position to discern the possible contributions his theory might make to the study of legal argumentation. What are the argumentation-theoretic implications of taking legal discourse as a necessary complement of rational moral discussion? Or of insisting that ideal models developed in argumentation theory can function as critical tools for legal discourse?

\section{Habermas's discourse theory and the discourse principle of rational consensus}

In his Theory of Communicative Action (1984/1987), Habermas develops a discourse theory that elaborates the rational-discursive elements implicit in social interaction as a form of verbal communication. His analysis depends on the core thesis that such communication involves the exchange of speech acts, through which social actors try to coordinate action by linguistic means. On this view, communicative action depends on the use of language as oriented to mutual understanding. Consequently, only speech acts that are verbally expressed and aimed at 
mutual understanding can have a function in a rational discussion aimed at rational consensus. His Moral Consciousness and Communicative Action (1990) further specifies the requirements of rational moral-practical discussions aimed at rational consensus. ${ }^{2}$ In this section, I first describe Habermas's ideas about the requirements of a rational consensus developed in his discourse theory (2.1) and then go on to address the relation between the rationality of moral and legal discourse (2.2).

\subsection{The theory of rational practical discourse and the communicative character of the rational acceptability of moral claims}

To characterize the various ways in which social actors can argue about claims in a rational discussion, Habermas distinguishes the ways in which people can argue about speech acts. When people exchange information, they presuppose that they meet the normal conditions of verbal communication. Normally, such assumptions, in Habermas's terms "claims to validity", are not made the subject of discussion, but information is exchanged against a shared background. The accepted norms for communication are the starting points that form the basis of this common background. ${ }^{3}$

If a claim to validity is questioned, the interlocutors can try to restore the consensus by opening a discussion or discourse (Diskurs) in which they try to reach a rational agreement about the acceptability of the claim on the basis of arguments. Habermas conceives argumentation as a dialogical process by means of which a proponent tries to convince the opponent of the acceptability of the validity claim. In his view, putting forward a validity claim presupposes an obligation to justify this claim if asked to do so. If the issue concerns a practical matter-one that involves a concrete course of action, general norm, or evaluation rather than a question of empirical truth - then the interlocutors engage in a practical discourse with the aim of reaching consensus on the question of whether the relevant normative or evaluative validity claim is justified.

Thus a central question of Habermas's discourse theory is how one can rationally justify moral commands, norms of action, ethical evaluations and the like through practical discussion. Starting from the perspective of communicative rationality, he develops a theory in which the rational acceptability of validity claims (e.g., moral commands, norms of action) depends on the way social actors coordinate their action by reaching agreement on the claim at issue.

The bulk of Habermas's efforts to articulate standards for practical discourse have focused on practical discourses concerned with the justification of norms (whether the norm is moral, institutional, legal, etc.). The various forms of such discourses of justification are subject to the following abstract discourse principle (D), which states the general requirement for the validity, or rational justification, of a norm in general: 
(D) Only those norms can claim to be valid that meet (or could meet) with the approval of all affected in their capacity as participants in a practical discourse (Habermas, 1990, 66; 1996, 107).

For moral discourses of justification, this general procedural principle is supplemented, or further specified, by a moral universalizability principle (U):

(U) All affected can accept the consequences and the side effects [the norm's] general observance can be anticipated to have for the satisfaction of everyone's interests (and these consequences are preferred to those of known alternative possibilities for regulation) (Habermas, 1990, 65)

In order to be valid, every moral norm that claims rational acceptability has to fulfill this condition. Thus (U) functions as a rule of moral argumentation that makes agreement in practical discourses possible whenever matters of concern to all are open to regulation in the equal interest of everyone. ${ }^{4}$ As a rule of argumentation or a logic for producing good reasons, $(\mathrm{U})$ belongs to the logic of practical discourses.

Habermas emphasizes that (U) presupposes a communicative context in which social actors need to coordinate their actions by discussing normative validity claims in everyday life. The problems arising in such a context cannot be handled monologically, but require collective reasoning: "By entering into a process of moral argumentation, the participants continue their communicative action in a reflexive attitude with the aim of restoring a consensus that has been disrupted. Moral argumentation thus serves to settle conflicts of action by consensual means" (Habermas 1990, 67). Actors can repair a disrupted consensus in two ways. They can either restore the intersubjective recognition of a validity claim that has become controversial, or they can arrive at an intersubjective recognition of a new validity claim that replaces the old one. In both situations the participants strive to reach an intersubjective understanding that is based on the fact that they are collectively convinced of the acceptability of the claim.

Participation in a practical discourse in accordance with (D) implies various presuppositions on various levels. Habermas (1990, 87ff.) distinguishes three levels of presuppositions of argumentation: the logical level of products, the dialectical level of procedures, and the rhetorical level of processes.

The presuppositions on the logical-semantical level concern the rules of a "minimal logic" and the consistency requirements proposed by Hare and others. These presuppositions have no ethical content. Drawing on Robert Alexy's analysis, ${ }^{5}$ Habermas provides examples of such logical rules as:

(1.1) No speaker may contradict himself.

(1.2) Every speaker who applies predicate $F$ to object $A$ must be prepared to apply $F$ to all other objects resembling $A$ in all relvant respects.

(1.3) Different speakers may not use the same expression with different meanings.

On the procedural level, argumentation involves a process in which proponents and opponents, relieved of the pressures of action and having adopted a 
hypothetical attitude toward the contested claim, strive to reach an understanding. This level is defined by those pragmatic presuppositions "necessary for a search for truth organized in the form of a competition" (Habermas, 1990, 87). Again he cites some examples from Alexy:

(2.1) Every speaker may assert only what he really believes

(2.2) A person who disputes a proposition or norm not under discussion must provide a reason for wanting to do so (ibid., 88).

Habermas considers rules such as those above as presuppositions of an unrestrained competition for better arguments. In his view, taking this approach to moral norms means rejecting traditional ethical philosophies insofar as these preserve a dogmatic core of fundamental convictions from all criticism.

On the rhetorical process level, argumentation involves a process of communication aimed at reaching rationally motivated agreement. For this level, Habermas spells out the requirements of a speech situation immune to repression and inequality - thus a form of communication that approximates ideal conditions. These presuppositions (which he originally described as the presuppositions of an "ideal speech situation") specify "the general symmetry conditions that every competent speaker who believes he is engaging in argumentation must presuppose as adequately fulfilled" (ibid.). Again, the formulations come from Alexy:

(3.1) Every subject with the competence to speak and act is allowed to take part in a discourse.

(3.2) (a) Everyone is allowed to question any assertion whatever.

(b) Everyone is allowed to introduce any assertion whatever into discourse.

(c) Everyone is allowed to express his attitudes, desires, and needs.

(3.3) No speaker may be prevented, by internal or external coercion, from exercising his rights laid down in (3.1) and (3.2) (ibid., 89).

Habermas (ibid., 90) considers these conditions as more than a potentially question-begging definition in favor of an ideal form of communication. Rather, they articulate the inescapable presuppositions of every form of rational practical discourse. Anyone who seriously engages in discourse as a process of rational argumentation aims to convince an opponent of the acceptability of a problematic validity claim by producing arguments in a practical discussion that satisfies the aforementioned pragmatic presuppositions.

To be sure, real discussions can, at most, approximate these conditions. However, the ideal of communicative rationality is not a mere theoretical construction or a utopian ideal. According to Habermas, the ideal of communicative rationality is presupposed in every discussion in which the participants try to convince each other with arguments. Furthermore, the ideal functions as a critical instrument for evaluating discussions conducted in everyday life. 


\subsection{The relation between rational moral discourse and rational discourse in legal settings}

Habermas $(1990,92)$ maintains that discourses take place in particular social contexts and are subject to the limitations of time and space. The participants are real human beings driven by other motives in addition to the single permissible motive of the search for truth. Topics and contributions have to be organized. The opening, conclusion, and re-opening of discussions must be arranged. Because of all these factors, institutional measures are needed to sufficiently neutralize empirical limitations and avoidable internal and external interference so that the idealized conditions always presupposed by the participants can at least be adequately approximated.

As a result, the analysis of real discourse is a complicated affair. If argumentation focuses exclusively on the justification of moral norms, then according to Habermas (ibid., 86, 92f.) the idealized pragmatic presuppositions imply the moral principle (U). But real discourse, particularly in legal-political domains, is not so pure, even when the issue is primarily a moral one. For one, the outcome is typically some legal norm or decision binding on a particular group omf citizens, with their own particular history and values. Thus Habermas (1996) is of the opinion that meeting the requirements of moral justification is not a sufficient condition for a rational outcome of legal discourses. Outcomes should also cohere with the existing legal order-its structure and decision-making procedures-as well as with various ethical-political and pragmatic standards that form part of the selfunderstanding and capabilities of a particular society. ${ }^{6}$ As Habermas (1996, 233$237 ; 1988,41-47$ ) argues, the law is not subordinate to morality, and therefore legal discourse is not subordinate to moral discourse but is rather intertwined with it. $^{7}$ Although legal procedures limit and enable moral argumentation in various ways, legal discourse is not a subset of moral discourse per se, but rather implements the broader discourse principle (D) for various legal-political contexts (Habermas 1988, 247 ; 1996, 230-37).

These complications must be kept in mind when we speak of law as institutionalizing moral discourse. Strictly speaking, legal discourse focuses on the justification of legal outcomes, not moral norms (Habermas 1996, 233f.). Moral considerations per se become relevant in legal discourse primarily insofar as legal outcomes (including the setting of policy goals) are supposed to satisfy standards of justice and impartiality (Habermas, 1988, 241ff.). Moreover, to the extent that legal discourse must address the moral acceptability of legal norms and decisions - and so must open up the space for moral argumentation - we can speak of legal discourses as a specific institutionalization of moral discourse (see Habermas $1988,247)$.

Note that the need to institutionalize practical discourse in, for example, parliamentary debate and legal procedure "does not contradict the partly counterfactual content of the presuppositions of discourse": 
On the contrary, attempts at institutionalization are subject in turn to normative conceptions and their goal, which spring spontaneously from our intuitive grasp of what argumentation is. This assertion can be verified empirically by studying the authorizations, exemptions, and procedural rules that have been used to institutionalize theoretical discourse in science or practical discourse in parliamentary activity (Habermas 1990, 92).

With respect to the institutionalization of practical discourse it is important to distinguish idealized rules of discourse (such as those illustrated in the previous section) from "conventions serving the institutionalization of discourses, conventions that help to actualize the ideal content of the presuppositions of argumentation under empirical conditions" (ibid.).

This institutionalization of discourse raises the question of how we should regard the rationality or legitimacy of the law and legal processes. Insofar as the law institutionalizes moral discourse, in what respects can legal processes still be considered rational, and what are the implications for the legitimacy of law? Habermas tries to solve the problem of the legitimacy of law by approaching the question of the justification of legal outcomes from the perspective of the communicative rationality of moral-practical discourse. He holds that the relation between law and communicative rationality is a complementary relationship that works in two directions.

On the one hand, law institutionalizes moral discourse as a form of conflict resolution within a polity as a legal community, thus complementing the limitations of everyday moral discourse with an impartial procedure for the decisive resolution of legal disputes. On the other hand, because the ideal of a rational discussion offers a critical instrument for testing the adequacy of decision-making in constitutional democracies, communicative rationality functions as a methodical tool for determining the legitimacy of law.

For argumentation theory, this complementary relation promises an interesting set of perspectives, suggesting that research into institutionalized forms of argumentation such as legal argumentation can be approached from two directions. On the one hand, we can ask how moral-practical discourses are supplemented by specific procedures and rules that promote a rational result; on the other hand, we can ask how general theories of argumentation can be used to criticize real processes of political and legal decision-making from the perspective of a rational discussion. In the following section I will establish what this complementary relation exactly amounts to.

\section{The complementary relation between legal discourse and communi- cative idealizations}

As we have seen, by considering moral and legal discourses as complementary, Habermas tries to explain the fact that on the one hand, institutionalized forms of discourse such as legal discourse are necessary to supplement everyday moral 
discourse and, on the other, legal discourse should adhere to the requirements underlying rational moral discourse. In this section, I describe what this complementary relation exactly amounts to for legal discourse.

Before discussing Habermas's complementarity thesis, it is important to situate his position with respect to other approaches to the law-morality relation. We can then appreciate his redefinition of legal validity. I thus begin by contrasting Habermas's view with those of Max Weber and Robert Alexy (3.1). I then take up the two sides of the complementarity thesis: Habermas's account of law as institutionalizing rational discussion on matters of public concern (3.2), and the discourse principle as a critical standard for legal discourse (3.3).

\subsection{Law, morality, and the relation between legal discourse and moral discourse}

In approaching the rationality of law from the perspective of discourse theory, Habermas redefines the validity of law in terms of discursive justification: valid legal norms must be rationally acceptable in the sense defined by the principle of rational discourse (D) and, insofar as justice issues are at stake, by the moral principle of universalizability (U). Thus he rejects the legal positivism that separates law and morality as two unrelated spheres. On a positivist account, the rationality of law depends not on moral criteria but simply on specifically legal criteria.

Habermas criticizes Weber $(1964,2: 160 f f$ ) for taking a positivist approach, that is, for holding that the rationality of law depends on whether laws are enacted in accordance with legally institutionalized procedures. In Weber's view, any fusion of law and morality threatens the rationality of law and thus the legitimacy basis of legal authority. In opposition to Weber's positivism, Habermas opts for an account that integrates formal-procedural and substantive modes of rationalitysuch that both the formal and the substantive aspects of law have an implicit moral dimension. On this view, legality derives its legitimacy from a procedural rationality that is based on the idea that legal processes should yield impartial solutions that can claim validity for all concerned. This form of rationality consists of an interlocking of moral-practical and institutional legal discourse: processes of moralpractical argumentation are institutionalized by means of legal procedures (Habermas, $1988,220,228$ ).

Following H. L. A. Hart $(1958 ; 1961)$ and others, Habermas contends that the law consists of substantive or "primary" norms on the one hand and, on the other hand, procedural or "secondary" norms that serve to institutionalize processes of legislation, adjudication, and administration. These secondary norms institutionalize legal discourse, which operates "not only under the external constraints of legal procedure but also under the internal constraints of a logic of argumentation for producing good reasons" (Habermas, 1988, 229).

From this perspective, legal discourse must meet the conditions of communicative rationality for discourse in general; therefore legal discourse is related to 
moral discourse. As already noted, law is not subordinate to morality but rather constitutes a specific institutionalization of morality defined by legal rules and procedures. But the moral principle becomes relevant for legal discourse insofar as such discourse involves moral reasons: legal discourse, although it is bound to existing law, cannot fully encapsulate itself within a closed universe of fixed legal rules. Modern law consists of both legal rules and general legal principles. As Habermas notes, "many of these principles are both legal and moral", as for example in constitutional law, where we find moral principles of natural law reproduced as positive law. From the perspective of a logic of argumentation, then, "the modes of justification institutionalized in legal processes and proceedings remain open to moral discourse".

On Habermas's approach, both moral and legal discourses are subject to criteria of discursive rationality captured in the discourse principle (D). In taking this view, he $(1996,229 \mathrm{ff}$.) opposes Alexy's $(1989,212-20)$ thesis that legal discourse can be considered to be a "special case" or subset of moral discourse. Habermas directs his criticism especially at Alexy's view that the rules of discourse are not selective enough to necessitate single right decisions (at which moral and legal discourses aim), and at his idea that the rationality of legal discourse is relative to the rationality of legislation. In Alexy's view, these limitations require us to supplement the universal rules of discourse with specific legal rules and argument forms. In Habermas's opinion, however, Alexy does not explain adequately how what these rules and argument forms taken from actual legal practice can be justified from the perspective of communicative rationality. Habermas argues that Alexy"s "special case thesis" has "the unpleasant consequence not only of relativizing the rightness of a legal decision, but of calling it into question as such" (Habermas 1996, 232). More specifically, Alexy's analysis, as Habermas reads it, loses sight of the deontological character of legal norms and decisions.

Habermas conceives rational discourse as an abstract formulation of the conditions for the rationality of discourse on different kinds of action norms. Moral argumentation and legal-political discourse are both forms of rational discourse subject to the discourse principle (D). For various forms of legal discourse, such as democratic procedures in the area of legislation and court procedures, specific rules of procedure must compensate for the fact that moral discourse cannot guarantee an impartial and decisive solution (ibid., 234). In his view, procedural law does not regulate normative-legal discourse as such but "secures, in the temporal, social and substantive dimensions, the institutional framework that clears the way for processes of communication governed by the logic of application discourses". Codes of procedure define the bounds within which parties can deal with the law strategically.

Because law and morality are both governed by discursive criteria of rationality, legal discourses can be conceived as rational discussions that are institutionalized through legal procedures and governed by the same principles of rational 
discourse as other forms of practical discourse, including moral discourse. To establish what this claim exactly amounts to, I begin with the first side of the complementarity relation, explaining how the law can promote rational discourse (3.2). I then turn to the second side and explain the moral acceptability of law from the perspective of a rational discussion (3.3).

\subsection{Law as an institutionalization of rational discourse}

The idea that law compensates for the cognitive indeterminacy of everyday moral discussion leads to the question of how the law can promote rational discussions that are also in accordance with the specific requirements of legal conflict-resolution.

Everyday moral discussions only partially meet the requirements of communicative rationality. Differences in power and competence often play an important role in such interactions. The participants typically have other motives than a cooperative search for the truth, and certain themes are excluded. Usually it is not clear how the discussion is organized and there are no fixed rules for opening, closing, and reopening it. The weaknesses of the incomplete procedural rationality of moral discourse make it understandable why specific matters require legal regulation and cannot be left to unstructured discussion. As Habermas $(1988,244)$ puts it, "Whatever the procedure by which we want to test whether a norm could find the uncoerced, that is, rationally motivated, consent of all who may possibly be affected, it guarantees neither the infallibility nor the unambiguity of the outcome, nor a result in due time". Further uncertainties arise in appropriately applying highly abstract rules to complex situations in a context-sensitive way.

In law, it is necessary that a decisive solution be guaranteed that still meets the requirements of communicative rationality as much as possible. Thus legal discourse requires certain "institutional precautionary measures" to promote the neutralization of impediments to rational discussion. According to Habermas (ibid., 245), "in all spheres of action where conflicts and pressures for regulation call for unambiguous, timely, and binding decisions, legal norms must absorb the contingencies that would emerge if matters were left to strictly moral guidance. The complementing of morality by coercive law can itself be morally justified".

The law institutionalizes and restricts moral-practical discourse in four ways. First, discourse is limited methodically, because it is tied to the valid law of the country. Second, it is limited substantively, by the subjects that can be discussed and by the division of the burden of proof. Third, it is limited socially, by the conditions for participation and by the division of roles. And fourth, it is limited temporally, by the time limits imposed on proceedings (ibid., 247).

The ways in which practical discussion is institutionalized in the law differ according to the different institutional contexts; for example, scholarly discourse within the legal academy, deliberations between lawyers and judges, and court- 
room proceedings all exhibit different discursive features. Moreover, important differences emerge between discourses concerned with the justification of legal norms as valid and discourses of application, which formulate singular judgments in light of norms that are already accepted as valid (see Habermas, 1998b).

\subsection{Norms for rational discourse as criteria for the rationality of legal discourse}

The other side of the complementary relation between law and moral discourse concerns the question of the rational acceptability of law as measured by standards of rational discourse-moral, ethical-political, and so on. If we focus specifically on the moral acceptability of law, then the question is whether legal procedures can foster outcomes that accord with the procedural implications of the moral principle $(\mathrm{U})$ and its underlying pragmatic presuppositions (see 2.1 above).

One such implication is that legal procedures be impartial. According to Habermas, in courtroom proceedings impartiality is guaranteed by the role of the judge as an impartial arbiter, by the principle of audi et altera partem (hearing both sides), by the rules for the division of the burden of proof, and by the judge's obligation to justify his decision.

Another implication is that laws-particularly those that bear on basic questions of justice-issue from a democratic process of deliberative decision-making governed by the idea of the free and equal participation of all citizens. According to Habermas, the requirement of universalizability also applies to laws insofar as they contain rules and principles that are generally applicable. For such matters, the best way to determine that laws are acceptable is to require unhindered discussions on the issue, open to all concerned parties and oriented toward gaining a consensus (to the extent possible). For Habermas $(1988,243,275)$, the projection of possible consensus on a law among all citizens (who are subject to the law) is a precondition for legitimacy.

Habermas regards constitutional democracy as the form of government that best meets these requirements, even though actual democratic decision-making is not always based on discursively achieved rational consensus. Various factors can make the actual process less than ideal: decisions often involve compromise rather than argued agreement, many citizens fail to participate in political discussion, and judges justify their decisions poorly. However, he contends that the ideal of impartiality still obtains: the ways in which we criticize deficiencies in the legal process reveal the ideal of impartiality residing at the heart of law, even though actual legal practice does not always completely accord with this ideal.

With respect to the ideal of rational consensus as formulated in the principles of communicative rationality - which includes not only moral but also ethicalpolitical, pragmatic, and legal standards for rational discourse-we must distinguish between discussions aimed at justifying norms as legally valid (the democratic process of legislation) and discussions aimed at applying a given valid norm 
in a given case (judicial procedures). Drawing on work by Klaus Günther (e.g., 1989), Habermas insists that communicative rationality operates not only in the process of justifying norms, but also in their application: "The legal procedures through which the impartiality of the administration of justice is supposed to be institutionalized must accord with this regulative idea of communicative rationality". In the context of justifying norms, discursive principles of communicative rationality "come into play through testing the universalizability of interests", whereas in application, communicative rationality sets standards of coherence for "an adequate and sufficiently complete comprehension of relevant contexts in the light of competing rules" (Habermas, 1988, 277).

Notice that in Habermas's view, discourse theory provides formal as well as substantive criteria of rationality. In response to Honneth's criticism (1986) that Habermas's proceduralist model of rationality does not take into account substantive moral criteria of rationality, ${ }^{10}$ Habermas (1986) argued that his discourse theory in fact contains two substantive moral principles: justice and solidarity. Justice implies equal respect and equal rights for all, solidarity implies empathy and care for the well-being of our fellow human beings. Habermas (1996,118ff.) argues that the legitimacy of law depends on the respect for basic rights such as the right to equal individual liberties or freedom of action guaranteeing private autonomy and the right to equal participation in the processes of democratic will-formation in parliamentary democracy. Citizens can exercise their political autonomy by participating in democratic processes that result in legitimate law."

To recapitulate, Habermas maintains that the ideal of communicative rationality provides both a heuristic instrument for reconstructing processes of legal decision-making and a critical instrument for evaluating such decision-making procedures and their legal outcomes. Discursive idealizations can also guide the critical analysis of legislative processes and other complex decision-making procedures. By evaluating the practice of legal conflict-resolution from the perspective of discursive idealizations, it becomes possible to determine the respects in which legal procedures approximate the conditions of rational discourse, and how they are distorted by external restrictions. For the practice of the application of law it is possible to investigate whether rules are violated in order to meet certain functional requirements, such as time limits.

\subsection{The complementarity thesis and research into legal argumentation}

Habermas's complementarity thesis implies that discursive principles of rationality govern both legal discourse and practical discourse in general, and that in legal contexts both forms of argumentation complement each other. This thesis offers interesting perspectives for argumentation theorists interested in the study of institutional discourse. More specifically, Habermas's proposals offer an explanation 
of why it makes sense to approach both general practical discourse and institutional legal discussions in parliaments and courtrooms as forms of rational discourse that can be assessed from the perspective of communicative rationality.

For argumentation theorists, the first side of the complementarity relation implies an investigation of the ways in which ideal procedures for rational discussion must be institutionalized for the sake of promoting solutions in accordance with rational ideals. The second side of the complementarity relation implies that theorists should study the ways in which procedures and rules for rational discourse provide standards for legal discourse and for the critique of argumentative practices in political and legal discussions.

\section{Habermas's account of the rationality of legal discourse and a research program for legal argumentation theory}

In this penultimate section I sketch some implications of Habermas's model for research on legal discourse from the perspective of a theory of legal argumentation-both its analysis and evaluation. More specifically, I examine implications of Habermas's thought for a research program inspired by the pragma-dialectical model of argumentation. As I hope to show, his analysis can provide the philosophical component for such a program. To motivate this claim, I sketch some further perspectives that Habermas opens up for research in legal argumentation.

To see the implications of Habermas's ideas for legal argumentation theory, we must first locate his claims in the context of the various components that constitute a research program in legal argumentation. Because he holds that a discourse theory should function as an analytical and critical tool for analyzing and evaluating legal discourse, it is important to establish in which respects his theory, in its present form, can fulfill these functions.

In their outline of a pragma-dialectical theory of argumentation, Frans $\mathrm{H}$. van Eemeren and Rob Grootendorst $(1992,5-9)$ argue that in a normative argumentation theory-one that proposes a normative ideal for analyzing and evaluating argumentation - the normative component should form part of a multifaceted research program that links the normative ideal to actual argumentative practices. Specifically, such a research program should consist of a philosophical, a theoretical, an analytical, an empirical, and a practical component. The philosophical and theoretical components represent the normative idealizations or criteria that inform the research, whereas the analytical, empirical, and practical components constitute the link between the normative ideal and research into actual forms of argumentation. ${ }^{2}$ After taking up the philosophical and theoretical components (4.1), I turn to the analytical, empirical, and practical components (4.2). 


\subsection{The normative ideal of rational legal discourse: the philosophical and theoretical components}

In my opinion, Habermas's discourse theory and complementarity thesis can be considered elements of the philosophical component of a research program on legal argumentation. This component develops the philosophical ideal of rationality for a theory of legal argumentation. His theory of rational practical discourse provides two general principles for rational consensus in moral discourse, (D) and (U). These principles represent an abstract formulation of the general prerequisites for rational moral discourse that also pertain to legal discourse. As Habermas (1984/ $1987,1: 26)$ admits, however, elaborating the import of these broad principles for the various levels of argumentation (product, procedure, and process) requires additional analysis. Moreover, the abstract principles (D) and (U) must be translated into legal settings and the context-specific prerequisites and principles that govern rational legal discourse; in the process one would have to clarify the respects in which these various requirements apply in the same way in both moral and in legal contexts. ${ }^{13}$

For Habermas's ideas to serve as a philosophical foundation for a theory of legal argumentation, we must also establish the similarities and differences between his ideal of rationality - with its pragmatic, dialectical, and critical presuppositions - and that of other approaches with pragmatic and dialectical starting points, such as the pragma-dialectical theory. In which respects does Habermas's consensual ideal differ from other ideals of rational dispute-resolution? How do the prerequisites of rational consensus that Habermas borrows from Alexy relate to the various kinds of preconditions for rational discourse as formulated in the pragmadialectical theory $?^{14}$ How do the ideal of rationality and the prerequisites for general practical discussions relate to the context-specific standards that govern rational legal discussions? For example, how can the ideal of legal certainty be understood from the standpoint of discursive idealizations operative in legal contexts?

In the theoretical component, one starts with the conception of rationality developed in the philosophical component and then attempts to show how the general ideal of rationality and the prerequisites of rational consensus in the legal sphere should be implemented as discussion rules for the resolution of legal disputes.

With respect to the discussion procedure, one specifies the ideal model of rational legal discourse by describing the various stages required for the resolution of disputes in legal contexts. One must show, for various forms of legal discourse, which contributions should play a role in the resolution of conflicts, and one must specify the relevant rules that define the rights and obligations of participants. ${ }^{15}$ One must also, to put it in Habermas's terms, elaborate the ways in which rules of legal procedure can promote a timely, unambiguous, and final resolution. Habermas $(1990,91)$ makes a distinction between the rules of rational discourse and the 
conventions that help to actualize the ideal content of the presuppositions of argumentation under empirical conditions. In my opinion, further study is required of the ways in which the legal rules institutionalize rational discourse, and of the precise status of rules that have a specifically legal character.

As Habermas recognizes, legal procedures and substantive law impose methodical, substantive, social, and temporal limits on rational argumentation. Each type of limitation opens up a corresponding perspective for theoretical research. Thus the methodical limitations imposed by the legal framework call for closer study of how legal discourse is tied to the law of the land and what these ties mean. Substantive limitations on legal discourse raise questions regarding the meaning of limitations on subject matter and the various distinctions connected with different burdens of proof. The social perspective points toward research into the implications of conditions on participation and the regulations of participant roles. From the temporal perspective, one should study the ways in which rules of procedure limit the number of possible contributions and impose time constraints for the sake of reaching a final decision within a reasonable amount of time.

As I have argued elsewhere (Feteris 1990; 1993), the pragma-dialectical ideal of rational discussion implies that legal procedures constitute a specific form of rational critical discussion. From this perspective, legal procedures provide additional rules necessary for a rational resolution of legal disputes. Such rules supplement, amend, or restrict more general pragma-dialectical rules for contexts in which various higher-order conditions are not met. Like Habermas, who argues that in law certain institutional measures are required to neutralize certain internal and external influences so as to approximate discursive idealizations, I regard certain legal rules and procedures as additional rules that are supposed to make it possible to resolve disputes rationally. This construal allows us to explain why certain procedural limitations with respect to the participants' behaviour are necessary.

For various forms of legal discourse such as scholarly discussions, court proceedings, and parliamentary debates, one must show how these implementations, additions, or restrictions can be justified in relation to the legal order as well as from the perspective of a rational discourse in the relevant legal context. Such questions refer to a broader issue than that of institutionalizing moral discourse: as already discussed above (2.2), the more general question concerns the means of promoting rational discourse and dispute-resolution in institutional contexts: do legal procedures indeed promote an impartial process of conflict resolution in accordance with the general requirements of a rational discussion?

In this context, one of the central questions of legal theory is this; how are judges supposed to apply rules of substantive law in their decisions and how should they justify those decisions? One cannot address these questions, which concern the rationality of application, simply in terms of the procedural rule that obliges judges to justify their decisions. As the literature in legal argumentation 
theory on the justification of legal decisions shows, one must also confront questions regarding the rationality of judicial justifications-questions concerning the normative implications of rational discourse theory for justifying a judicial decision to apply a particular legal rule in a concrete case. These questions provide the central focal points in various theories of legal argumentation that approach the justification of a legal decision from the perspective of rational discourse (e.g., Aarnio, 1977; 1987; Alexy, 1989; MacCormick, 1978; Peczenik, 1983; 1989; Summers, 1978; Wróblewski, 1992; for an overview, see Feteris, 1999a).

Habermas's proposals provoke an important question concerning the relation between the legal and moral aspects of the arguments used in the justification of a legal decision. In traditional theories of legal argumentation, arguments based on legal rules and other acknowledged legal sources, and employing accepted forms of legal argumentation, are to be preferred above such legal sources as moral principles and interpretative methods based on the intentions of a rational legislator. What consequences does Habermas's integration of moral criteria in the ideal of rational legal argumentation have for standards governing the employment of various forms of moral arguments in the context of a rational legal discussion?

\subsection{The link with actual legal discourses: analytical, empirical, and practical} components

To analyze and evaluate actual practices of legal argumentation, the theory should be supplemented by an analytical component that specifies how actual processes of argumentation can be reconstructed in terms of the theory. Actual forms of legal argumentation should undergo some form of analytic interpretation in terms of the theoretical model. The central question is how legal discourse can be reconstructed in such a way that all those, and only those, aspects are highlighted that are relevant in view of the ideal model that determines the focus of attention (see van Eemeren and Grootendorst, 1992, 7).

The "translation" of actual processes of legal decision-making (e.g., parliamentary discussions and court proceedings) in terms of a rational discussion is not always unproblematic. As 1 have shown in various publications (Feteris, 1991, 2002,2003 ), to apply the normative model to legal contexts one must translate legal procedures and legal forms of argumentation into the framework of procedures and argument-forms envisioned in the general theory.

In the empirical component, one must describe how participants in actual legal discourse produce, identify, and evaluate legal argumentation; moreover, one should pinpoint the factors that influence the outcome of legal discussions. Among other questions, one must solve the problem of how to understand and justify the theoretical analysis of legal argumentation on the basis of knowledge of the rules and principles that guide actual argumentative processes.

Relevant questions in this context include the following: Do the ways in which procedures are conducted and the ways in which judicial decisions are justified 
meet the requirements of legal and moral-practical rationality? How can participants in legal discourse act strategically within the boundaries specified by the procedural and substantive rules of law? An analysis and evaluation of actual legal discussions must show whether certain rules are violated in order to meet certain functional requirements and how procedural restrictions allow for strategic manoeuvring. ${ }^{16}$

For various forms of legal process, one can investigate the role of procedures and discursive norms. With respect to procedural rationality, one can examine whether, in legal fields in which moral points of view play an important role, idealized criteria of general acceptability are actually taken into account in processes of legislation, and whether the procedures followed meet the ideal requirements of practical rationality. With respect to substantive aspects of rationality, one can inquire into the kinds of arguments that can constitute an acceptable justification of a legal claim; one can also ask how these different kinds of argument-political, legal, and moral-complement each other in the context of practical discussions in the legal sphere. Does the combination of political, legal, and moral perspectives have consequences for the relevance and adequacy of various forms of arguments?

Finally, in the practical component, one puts the philosophical, theoretical, analytical, and empirical insights to use for developing methods for improving argumentative practice. Here one must examine possible ways of methodically increasing people's skills and abilities for the production of legal argumentative discourse as well as for its analysis and evaluation.

\section{Conclusion}

Habermas offers a philosophical justification for conceiving legal discourse as a form of rational discourse. Inasmuch as the latter involves moral modes of argumentation, legal discourse and moral-practical discourse are complementary, which implies that legal discourse is an institutionalized form of moral discourse and should therefore be evaluated, at least in part, from the perspective of the normative idealizations that govern rational moral discussion. For argumentation theorists, this philosophical justification offers interesting perspectives for research on legal discourse. On the one hand, we can ask how legal procedures of conflict resolution institutionalize rational discussions. On the other hand, we can ask whether such legal procedures can sufficiently approximate discursive idealizations.

Generally speaking, Habermas's views suggest two important lines of research for argumentation theorists interested in legal discourse as an institutionalized form of rational discussion. The first line of research would concentrate on the ways in which legal discussions must compensate for the limitations of everyday moral discussions. The second line would concentrate on the use of ideal models of discourse as a source of critical standards for the analysis and evaluation of the actual practice of legal discourse in various institutional settings. 
To illustrate how research on the basis of Habermas's ideas could be carried out, I have situated his philosophical analysis in the framework of a research program in legal argumentation. Using the distinction among research components as developed in the pragma-dialectical approach, I have described a number of research-worthy questions that Habermas's complementarity thesis suggest for a pragma-dialectical research program focused on the relation between institutionalized legal discourse and informal modes of discussion in everyday life. The further lines of lines of research opened up by such questions could contribute to a better understanding of the similarities and differences between general practical discussions in the moral sphere and discussions in the legal sphere.

\section{Notes}

'For further literature, see Rasmussen (1990), Rehg (1994), White (1995), Rehg's translator's introduction to Habermas (1996), and Rosenfeld and Arato (1998).

${ }^{2}$ The two books 1 mention in this paragraph are translations of Theorie des kommunikativen Handelns (Frankfurt am Main: Suhrkamp, 1981) and Faktizitat und Geltung. Beiträge zur Diskurstheorie des Rechts und des demokratischen Rechtsstaats (Frankfurt am Main: Suhrkamp, 1992).

${ }^{3}$ For a discussion of the concept of the "lifeworld", see Habermas (1987, 119-52; 1998a, ch. 4).

${ }^{4}$ Habermas's principle of universalizability (U) can be considered a dialogical reformulation of Kant's categorical imperative. That a norm should be universally applicable is not determined by the individual but in a discursive testing with others; see Habermas (1990, 67); also Chambers $(1995,236 \mathrm{ff})$ and Rehg $(1994,38)$. Consequently, Habermas $(1990,66)$ regards (U) as a principle that precludes a monological approach: as a principle that regulates argumentation among a plurality of participants, (U) calls for an actual argumentative process to which all affected are admitted as participants. In this respect it differs from John Rawls's original position. For a comparison of Habermas's procedural theory with that of Rawls, see Baynes $(1995,207 \mathrm{ff})$ and Moon (1995, 143ff).

${ }^{5}$ See Alexy (1989); Feteris (1999a) provides a complete description of the theory of Alexy; for a critical review of Alexy's rules, see Feteris (1992).

${ }^{6} \mathrm{Cf}$. Rehg $(1994,219,222-223)$ who argues that the legitimacy of law must be measured against a range of idealizations in addition to the moral principle (U), for example the technical-pragmatic assessment of efficient means and strategies and the nondiscursive ideals of fair compromise formation.

${ }^{7}$ Rehg $(1994,218)$ characterizes Habermas's idea that the two types of discourse intertwine or interpenetrate as the "interpenetration thesis". On the one hand "the presence of the moral component lends legitimacy to the outcome produced by following definite institutionalized legal procedures", on the other hand "these legal procedures instantiate moral idealizations in some sense". This formulation, however, seems to equate the interpenetration and complementarity theses. Although the two are closely related, they highlight different aspects of the law-morality relation, that is, complementarity articulates the effect of interpenetration.

"See Habermas $(1988,229-230)$. Habermas's thesis that legal procedures compensate for the shortcomings of practical discourse represents a shift from an earlier position he defended in a discussion with Luhmann (Habermas, 1971, 200ff). At that time he viewed institutionalized legal processes as a mode of strategic action that does not aim at reaching rational consensus. In criticizing this strategic model, Alexy $(1981,287-288)$ argued that legal processes represent a 
specific form of a rational discussion that takes place under restricting circumstances. This criticism led Habermas (1984/1987, 1:412 note 49) to change his original opinion: he now considers legal processes as a form of communicative action.

${ }^{9}$ Habermas $(1996,235)$; to illustrate this point, he refers to the German Code of Civil Procedure and Code of Criminal Procedure (ibid., 235-37).

${ }^{16} \mathrm{Bal}$ (1996) levels a similar criticism, arguing that Habermas's procedural theory lacks substantive moral starting points.

${ }^{11} \mathrm{Bal}$ (1996) takes this thesis-that legitimate law depends on a system of basic rights-a step further when he argues that human rights can supply starting-points for practical-legal discourse; thus, the legitimacy of law resides in the minimal moral substance of human rights. According to Bal (ibid., 91), by taking human rights "seriously" in substantive debates on criminal law matters, one gains a moral counterbalance for predominantly instrumental criminal policies.

${ }^{12}$ See Feteris (1999a, 203-204) for an outline of such a research program for legal argumentation. ${ }^{13}$ For a formulation of such principles for the legal context, see Aarnio, Alexy, and Peczenik (1981).

${ }^{14}$ For a comparison between the pragma-dialectical conditions for a rational discussion and the institutional modes of compensation for certain shortcomings in a legal context, see Feteris (1990).

${ }^{15}$ For a description of the various stages of a critical discussion and the contributions that contribute to rational dispute-resolution, see van Eemeren and Grootendorst (1992).

${ }^{16}$ See Feteris (1999b) for a critical analysis of an actual criminal case from the perspective of a rational discussion.

\section{References}

Aarnio, A. (1977), On Legal Reasoning. Turku: Turun Yliopisto.

Aarnio, A. (1987). The Rational as Reasonable. Dordrecht: Reidel.

Aarnio, A., R. Alexy, A. Peczenik (1981). The Foundation of Legal Reasoning. Rechtstheorie, 21, 133-158, 257-279, 423-448.

Alexy, R. (1981). Die Idee einer prozeduralen Theorie der juristischen Argumentation. In A. Aarnio, N. Niiniluoto, J. Uuusitalo (Eds.), Methodologie und Erkenntnistheorie der juristischen Argumentation (pp. 177-188). Berlin: Duncker and Humblot.

Alexy, R. (1989). A Theory of Legal Argumentation. Oxford: Clarendon.

P. Bal (1996). Discourse Ethics and Human Rights in Criminal Procedure. See Deflem (1996, 72-99).

Baynes, K. (1995). Democracy and the Rechtsstaat: Habermas's Faktizität und Geltung. See White (1995, 201-232).

Chambers, S. (1995). Discourse and Democratic Practices. See White (1995, 233-262).

Deflem, M. (Ed.) (1996). Habermas, Modernity and Law. London: Sage.

Eemeren, F. H. van, and R. Grootendorst (1992). Argumentation, Communication, and Fallacies. Hillsdale, NJ: Erlbaum.

Eemeren, F.H. van, R. Grootendorst, and F, Snoeck Henkemans (1996). Fundamentals of Argumentation Theory. Mahwah, NJ: Erlbaum.

Eemeren, F.H. van, R. Grootendorst, S. Jackson, and S. Jacobs (1993). Reconstructing Argumentative Discourse. Tuscaloosa: University of Alabama Press. 
Feteris, E.T. (1990). Conditions and Rules for Rational Discussion in a legal process: A Pragma-Dialectical Perspective. Argumentation and Advocacy, 26, 108-117.

Feteris, E.T. (1991). Normative Reconstruction of Legal Discussions. In van Eemeren et al. (Eds.), Proceedings of the Second International Conference on Argumentation (pp. 768-775). Amsterdam: SicSat.

Feteris, E.T. (1992). Review of R. Alexy. A theory of Legal Argumentation: The Theory of Rational Discourse as Theory of Legal Justification. Argumentation, 6, 131-133.

Feteris, E.T. (1993). Rationality in Legal Discussions: A Pragma-Dialectical Perspective. Informal Logic, 15, 179-188.

Feteris, E.T. (1999a). Fundamentals of Legal Argumentation. Dordrecht: Kluwer.

Feteris, E.T. (1999b). What Went Wrong in the Ball-Point Case? An Argumentative Analysis and Evaluation of the Discussion in the Ball-Point Case. In M. Malsch and J.F. Nijboer (Eds.), Complex cases: perspectives on the Netherlands Criminal Justice System (pp. 159-178). Amsterdam: Thela Thesis.

Feteris, E.T. (2002). The Role of Arguments from Consequences in Legal Argumentation. In H.V. Hansen and C. Tindale (Eds.), Argumentation and its applications. Proceedings of the OSSA Conference on Argumentation, Windsor May 17-19, 2001.

Feteris, E.T. (2003). The Pragma-Dialectical Analysis and Evaluation of Teleological Argumentation in a Legal Context. In F.H. van Eemeren and P. Houtlosser (Eds.), The Practice of Argumentation. Amsterdam/Philadelphia: Benjamins (forthcoming).

Günther, K. (1989). Ein normativer Begriff der Kohärenz: Für eine Theorie der juristischen Argumentation. Rechtstheorie, 20, 163-190.

Habermas, J. (1971). Theorie der Gesellschaft oder Sozialtechnologie? Eine Auseinandersetzung mit Niklas Luhmann. In J. Habermas and N. Luhmann, Theorie der Gesellschaft oder Sozialtechnologie?(pp. 101-141). Frankfurt am Main: Suhrkamp.

Habermas, J. (1979). Communication and the Evolution of Society (T.A. MacCarthy, Trans.). Boston: Beacon.

Habermas, J. (1984/1987). The Theory of Communicative Action (T. McCarthy, Trans.). 2 vols. Boston: Beacon.

Habermas, J. (1984). Vorstudien und Ergänzungen zur Theorie des Kommunikativen Handelns. Frankfurt am Main: Suhrkamp.

Habermas, J. (1986). Moralität und Sittlichkeit: Treffen Hegels Einwände gegen Kant auch auf die Diskursethik zu? In W. Kuhlmann (Ed.), Moralität und Sittlichkeit (pp. 16-37). Frankfurt am Main: Suhrkamp.

Habermas, J. (1988). Law and Morality (K. Baynes, Trans). In S.M. McMurrin (Ed.), The Tanner Lectures on human values, Vol. 8 (pp. 217-279). Salt Lake City: University of Utah Press.

Habermas, J. (1990), Moral Consciousness and Communicative action. Cambridge, MA: The MIT Press.

Habermas, J. (1996), Between Facts and Norms (W. Rehg, Trans.). Cambridge, MA: MIT Press.

Habermas, J. (1998a), On the Pragmatics of Communication, (M. Cooke, Ed.). Cambridge, MA: MIT Press. 
Habermas, J. (1998b). Reply to Symposium Participants, Benjamin N. Cardozo School of Law (W. Rehg, Trans.). See Rosenfeld and Arato (1998, 381-452).

Hart, H.L.A. (1958). Positivism and the Separation of Law and Morals. Harvard Law Review, 71, 593-629.

Hart, H.L.A. (1961). The Concept of Law. Oxford: Oxford University Press.

Honneth, A. (1986). Diskursethik und implizites Gerechtigkeitskonzept. In W. Kuhlmann

(Ed.), Moralität und Sittlichkeit (pp. 183-193). Frankfurt am Main: Suhrkamp.

MacCormick, N. (1978). Legal Reasoning and Legal Theory. Oxford: Clarendon.

Moon, J.D. (1995). Practical Discourse and Communicative Ethics. See White $(1995,143$ 166).

Peczenik, A. (1983). The Basis of Legal Justification. Lund: no publisher.

Peczenik, A. (1989). On Law and Reason. Dordrecht: Reidel.

Perelman, $\mathrm{C}$, and L. Olbrechts-Tyteca (1958). La nouvelle rhétorique. Brussels: l'Université de Bruxelles.

Rasmussen, D.M. (1990). Reading Habermas. Oxford: Blackwell.

Rehg, W. (1994). Insight and Solidarity. Berkeley: University of California Press.

Rosenfeld, M., A. Arato (Eds.) (1998). Habermas on Law and Democracy. Berkeley: University of California Press.

Summers, R. (1978). Two Types of Substantive Reasons: The Core of a Theory of Common-Law Justification, Cornell Law Review, 63, 707-788.

Toulmin, S.E. (1958). The Uses of Argument. Cambridge: Cambridge University Press. Weber, M. (1964). Wirtschaft und Gesellschaft. Cologne: Kiepenheuer and Witsch. White, S.K. (Ed.) (1995). The Cambridge Companion to Habermas. Cambridge: Cambridge University Press.

Wróblewski, J. (1992). The Judicial Application of Law (Z. Bankowski and N.MacCormick. Eds). Dordrecht: Kluwer.

Eveline T. Feteris Department of Speech Communications, Argumentation Theory, and Rhetoric Universiteit van Amsterdam Spuistraat 134 1012 VB Amsterdam Netherlands email: e.tfeteris@uvanl 